\title{
Perspectives on biotechnological applications of archaea
}

\author{
CHIARA SCHIRALDI, ${ }^{1}$ MARIATERESA GIULIANO ${ }^{1}$ and MARIO DE ROSA ${ }^{1,2}$ \\ ${ }^{1}$ Department of Experimental Medicine, Section of Biotechnology and Molecular Biology, Faculty of Medicine, II University of Naples, via \\ Costantinopoli 16, 80138 Naples, Italy \\ ${ }^{2}$ Author to whom correspondence should be addressed (mario.derosa@ unina2.it)
}

Received October 15, 2001; accepted May 6, 2002; published online May 31, 2002

Summary Many archaea colonize extreme environments. They include hyperthermophiles, sulfur-metabolizing thermophiles, extreme halophiles and methanogens. Because extremophilic microorganisms have unusual properties, they are a potentially valuable resource in the development of novel biotechnological processes. Despite extensive research, however, there are few existing industrial applications of either archaeal biomass or archaeal enzymes. This review summarizes current knowledge about the biotechnological uses of archaea and archaeal enzymes with special attention to potential applications that are the subject of current experimental evaluation. Topics covered include cultivation methods, recent achievements in genomics, which are of key importance for the development of new biotechnological tools, and the application of wild-type biomasses, engineered microorganisms, enzymes and specific metabolites in particular bioprocesses of industrial interest.

Keywords: biotechnology, extremozymes, high density cultivation, recombinant DNA technology.

\section{Introduction}

Woese et al. (1977) recognized that the Prokarya comprise two distinct domains, namely the Bacteria and the Archaea. The original classification based on $16 \mathrm{~S}$ rRNA has been confirmed by extensive phylogenetic studies on a variety of macromolecules found in the patrimony of these microbes. Systematic classification of the Archaea, which are generally believed to originate from a single ancestor, has identified several major clusters based on physiological characteristics: hyperthermophiles (optimal growth temperatures higher than $70^{\circ} \mathrm{C}$ ); methanogens (anaerobes with growth temperatures ranging from 0 to $100{ }^{\circ} \mathrm{C}$ ); extreme halophiles or Euryarchaeota (requiring high saline solutions, up to $20 \%$ sodium chloride, for growth); and sulfur-metabolizing thermophilic bacteria or Crenarchaeota.

Many archaea are extremophiles, microbes that not only tolerate, but grow optimally in habitats normally considered too severe for life. Although several extremophilic microorganisms have been known for 40 years, the search for extremophiles has intensified in the last decade for two main reasons. First, the range of conditions under which life can exist is now known to be much broader than previously thought, and this has led to the exploration of many hitherto uninvestigated habitats. Second, it is now recognized that attributes of organisms adapted to extreme environments have the potential to serve a wide array of industrial purposes.

Archaea possess genes with recognizable counterparts in the Bacteria, showing that the two groups have functional similarities. Archaea also possess genes otherwise found only in Eukarya. Nevertheless, most signature genes present in archaeal genomes have no known function and no homologs outside of the Archaea (Graham et al. 2000). Because much of the genetic patrimony of the Archaea appears to be unique, many genomic studies are currently in progress (Table 1) to identify the functions of archaea-specific genes and thereby gain a better understanding of cellular processes in archaea.

In addition to unique amino acid sequences, extrinsic factors (e.g., protein folding systems) may be involved in extremophilic adaptation. Increasing the size of the genomic data set will indicate whether some adaptations are dependent on specific amino acid sequences or structural contexts (Haney et al. 1999). To this end, comparative studies of protein sequences from mesophilic and extremely thermophilic homologous microorganisms are needed. Haney et al. (1999) conducted such a study on Methanococcus species. Comparative studies at the molecular level (e.g., G + C content) or of amino acid alignment are also needed to identify highly conserved residues.

Many interesting enzymes have been isolated from extremophilic microbes (sometimes called extremozymes) (Hough and Danson 1999, Schumacher et al. 2001). Specific archaeal metabolites have also been purified and characterized and some of them have potential industrial uses. However, several technical difficulties have prevented the large-scale industrial application of enzymes and special metabolites from extremophilic sources, the most important being the availability of these compounds. Large-scale archaeal cultures are difficult to set up: medium evaporation has to be taken into account for hyperthermophilic cultures, and fermenters must be built of materials resistant to corrosion by the media required for growth of alkaliphiles, acidophiles and, particularly, halophiles. In addition, it is well established that the basal expression level of archaeal enzymes, although sufficient for their purification and characterization on a laboratory scale, is low 
Table 1. List of completed genome sequences (sources: The Institute for Genomic Research (TIGR, Rockville, MD) and PUBMED).

\begin{tabular}{|c|c|c|c|}
\hline \multicolumn{2}{|l|}{ Microorganisms } & \multirow[t]{2}{*}{ Size $(\mathrm{Mb})$} & \multirow[t]{2}{*}{ Reference } \\
\hline Order & Species & & \\
\hline \multicolumn{4}{|l|}{ Crenarchaeota } \\
\hline Desulfurococcales & Aeropyrum pernix K1 & 1.6 & Kawarabayasi et al. 1999 \\
\hline \multirow[t]{2}{*}{ Sulfolobales } & Sulfolobus solfataricus $P 2$ & 2.9 & She et al. 2001 \\
\hline & Sulfolobus tokodaii & 2.7 & Kawarabayasi et al. 2001 \\
\hline \multicolumn{4}{|l|}{ Euryarchaeota } \\
\hline Archaeoglobales & Archaeoglobus fulgidus DSM 4304 & 2.1 & Klenk et al. 1997 \\
\hline Halobacteriales & Halobacterium sp. $N R C-1$ & 2.0 & $\mathrm{Ng}$ et al. 2000 \\
\hline Methanobacteriales & Methanobacterium thermoautotrophicum $\Delta H$ & 1.7 & Smith et al. 1997 \\
\hline \multirow[t]{2}{*}{ Methanococcales } & Methanococcus jannaschii DSM 2661 & 1.6 & Bult et al. 1996 \\
\hline & Methanosarcina acetivorans $\mathrm{C} 2 \mathrm{~A}$ & 5.7 & Galagan et al. 2002 \\
\hline Methanopyrales & Methanopyrus kandleri & 1.7 & Slesarev et al. 2002 \\
\hline \multirow[t]{2}{*}{ Thermococcales } & Pyrococcus horikoshii (shinkaj) OT3 & 1.7 & Kawarabayasi et al. 1998 \\
\hline & Pyrococcus abyssi GE5 & 1.7 & unpublished \\
\hline \multirow[t]{2}{*}{ Thermoplasmales } & Thermoplasma acidophilum DSM 1728 & 1.5 & Ruepp et al. 2000 \\
\hline & Thermoplasma volcanium GSS 1 & 1.5 & Kawashima et al. 2000 \\
\hline
\end{tabular}

with respect to that required for industrial purposes (Kelly and Deming 1988, Cowan 1992, Herbert 1992, Madigan and Marrs 1997). As a consequence, scientific interest has focused both on the design of innovative bioreactors to achieve higher biomasses and metabolite production rates, and on the development of techniques for cloning and expressing archaeal enzymes in mesophilic cell factories. The successful coupling of these strategies has been demonstrated in several applications (Nordberg Karlsson et al. 2000, Schiraldi et al. 2000, 2001).

In addition to the development of industrial production processes, basic research is also needed to determine how enzymes have adapted to extreme conditions at the molecular level. It has been shown that the modifications used by enzymes of psychrophiles to permit conformational flexibility at low temperatures are opposite to those that confer thermostability to proteins of thermophiles (Russell 2000). Correlating the genetic code with specific chemico-physical characteristics provides a promising new approach to the development of customized industrial biocatalysts.

Because of the diversity of research related to the development of biotechnological processes employing archaea, we have limited this review to a discussion of novel achievements in three fields: (1) innovative fermentation processes for production of archaeal biomass, enzymes and metabolites; (2) cloning and expression strategies for archaeal enzymes, as a tool for their large-scale production; and (3) the industrial potential of archaea and their enzymes or specific metabolites.

\section{Innovative fermentation processes for the production of archaeal biomass, enzymes and metabolites}

A major limitation to the industrial application of archaeal enzymes and metabolites is the low productivity of the fermentation processes as a result of low growth rates and low biomass yields. To overcome these limitations, attention has been focused on studying the physiology of archaea of biotechnologi- cal interest and on designing bioreactors and bioprocesses that increase productivity. Because of the unconventional environmental conditions needed for the cultivation of extremophiles, contamination problems are minimal. Therefore, a continuous culture approach has been widely adopted.

Continuous culture experiments have provided insights into the significance of specific enzymes, in addition to clarifying stress responses and unusual physiological characteristics of hyperthermophilic and extremely thermoacidophilic microorganisms. To improve biomass yield of the hyperthermophilic archaeon Pyrococcus furiosus, Raven et al. (1992) used continuous cultures with defined and minimal media and achieved a maximal cell density of $10^{8}$ cells $\mathrm{ml}^{-1}$ when $P$. furiosus was grown on starch (Raven and Sharp 1997). Rinker et al. (1999) cultivated the hyperthermophilic heterotrophs Metallosphera sedula, P. furiosus and Thermococcus litoralis in a chemostat (Table 2) and observed the production of exopolysaccharides. Continuous cultures of Methanobacterium thermoautotrophicum were performed at different gassing rates using continuous measurements of the growth-limiting factor $\mathrm{H}_{2}$, and a simple unstructured mathematical model was developed and verified (Schill et al. 1999). Another extremely thermophilic methanogen, Methanococcus jannaschii, was grown in continuous culture to evaluate the correlation between hydrogenase activity and parameters such as growth rate and pressure (Tsao et al. 1994). Optimization of the growth medium is also of key importance in the production of extremophilic biomasses for subsequent exploitation in industry.

Particular interest has focused on the cultivation of anaerobic archaea, because their sensitivity to oxygen is a major obstacle to cultivation and to the development of genetic exchange systems in archaea. Rothe and Thomm (2000) reported the replacement of $\mathrm{Na}_{2} \mathrm{~S}$ with $\mathrm{Na}_{2} \mathrm{SO}_{3}$ to protect the culture from oxygen, even outside the anaerobic chamber, thus simplifying the cultivation method. Godfroy et al. (2000) exploited a gas-lift bioreactor for the continuous culture of 
Table 2. Bioreactor scale cultivation of archaea: continuous and high cell density fermentation. Abbreviation: $T_{\mathrm{opt}}=$ optimal growth temperature

\begin{tabular}{llll}
\hline Microorganism & $T_{\text {opt }}\left({ }^{\circ} \mathrm{C}\right)$ & Cultivation mode & Reference \\
\hline Metallosphera sedula & 74 & Continuous & Rinker et al. 1999 \\
Methanobacterium thermoautotrophicum & 65 & Continuous growth-limiting factor $\mathrm{H}_{2}$ & Schills et al. 1996 \\
Methanococcus jannaschii & 85 & Medium optimization CSTR & Mukhopadhyay et al. 1999 \\
Methanococcus jannaschii & $80-85$ & Continuous & Tsao et al. 1994 \\
Pyrococcus abyssi ST549 & 95 & Continuous & Godfroy et al. 2000 \\
Pyrococcus furiosus & 90 & Dialysis & Krahe et al. 1996 \\
Pyrococcus furiosus & 90 & Continuous & Raven et al. 1992 \\
Pyrococcus furiosus & 90 & Batch on starch-based medium & Raven and Sharp 1997 \\
Pyrococcus furiosus & 98 & Continuous & Rinker et al. 1999 \\
Sulfolobus shibatae & 75 & Dialysis & Krahe et al. 1996 \\
Sulfolobus solfataricus G $\theta$ & 75 & Microfiltration & Schiraldi et al. 1999 \\
Sulfolobus solfataricus MT4 & 87 & Batch on whey-based medium & Romano et al. 1992 \\
Thermococcus barosii & 82.5 & & Duffaud et al. 1998 \\
Thermococcus litoralis & $85-88$ & Batch and continuous & Rinker and Kelly 2000 \\
\hline
\end{tabular}

Pyrococcus abyssi ST549 on carbohydrates, proteinaceous substrates or amino acids and found that the disaccharides maltose and cellobiose did not support growth, whereas proteinaceous materials, such as peptone or amino acids in the presence of sulfur, were good substrates.

The use of waste products as substrates for extremophilic biomass production is an attractive option for producing enzymes and metabolites for commercial exploitation. Sulfolobus solfataricus MT4 grown at $87^{\circ} \mathrm{C}$ in a $100-1$ fermenter on whey supplied directly from dairy farms yielded $80 \mathrm{~g}$ of dry biomass per mole of lactose (Romano et al. 1992).

Research attention has also focused on the development of culture techniques that result in high cell densities. To date, successful approaches for improving biomass yield and enzyme or metabolite production have involved either fed-batch cultures or the development of special bioreactors that allow easy removal of toxic metabolites and replacement of nutrients. Efficient production of Sulfolobus solfataricus DSM 1617 was achieved by a fed-batch technique (Park and Lee 1997, 1999). In these studies, maximum cell yield (dry biomass) was $23 \mathrm{~g}^{-1}$, when constant volume was maintained by continuous replacement of evaporated water. The kinetic parameters and a mathematical model of the fermentation process were evaluated. The effects of yeast extract and other complex components on metabolite formation (e.g., ammonia) and cell yield were also reported.

A novel corrosion-resistant bioreactor composed of polyetherether ketone, tech glass (borosilicate glass), silicium nitrate ceramics and silicon nitrite ceramics was used for the cultivation of two recently isolated extreme halophilic archaea that produce poly- $\gamma$-glutamic acid and poly- $\beta$-hydroxybutyric acid, respectively (Hezayen et al. 2000). Batch fermentations on $n$-butyric acid as carbon source yielded a cell density (dry biomass) of $2.3 \mathrm{~g}^{-1}$, with the accumulation of poly- $\beta$-hydroxybutyric acid comprising up to $53 \%$ of the dry biomass.

Although the application of fed-batch techniques coupled with media optimization have facilitated in vitro culture of archaea in sufficient quantities to permit physiological studies and the isolation of numerous enzymes of industrial interest, it has not been possible to scale-up these techniques for largescale production. To overcome this limitation, several groups have focused on bioreactor design in an attempt to couple fermentation with membrane separation processes, and thereby overcome problems associated with the toxicity of accumulated metabolites. A novel dialysis bioreactor was designed and developed at the Technical University of Hamburg and used to study the influence of parameters such as gassing rate, substrate supplementation and agitation on growth rate of Pyrococcus woesei (Rüdiger et al. 1992). Krahe et al. (1996) used a dialysis process to obtain high cell densities of three thermophilic strains, two of which were from the domain Archaea. A final cell density (dry biomass) of $110 \mathrm{~g} \mathrm{l}^{-1}$ was achieved in $350 \mathrm{~h}$ for Sulfolobus shibatae, whereas cultivation of Pyrococcus furiosus yielded a maximal cell density of $3 \times 10^{10}$ cells $\mathrm{ml}^{-1}$, corresponding to a 20 -fold increase compared with the batch process.

We used a novel microfiltration (MF) technique for the high-density cultivation of thermoacidophilic archaea. The MF bioreactor consisted of a traditional fermentation vessel modified next to the baffles by the insertion of two MF modules made of polypropylene capillaries (see Figure 1). To prolong the growth phase of the microorganisms, the fermentation process was divided into three consecutive phases: batch, fed-batch and MF. The bioreactor has been used for about 100 runs over more than a year without loss of filtration capacity. We obtained high yields of $S$. solfataricus $\mathrm{G} \theta$, corresponding to a 15-fold increase in biomass (maximal cell dry biomass of $38 \mathrm{~g}^{-1}$ ) compared with batch culture. The cells maintained active synthesis of reporter enzymes of industrial interest, including $\alpha$-glucosidase, $\beta$-glycosidase and alcohol dehydrogenase (Schiraldi et al. 1999, 2001). Although we obtained improved biomass yield with the MF bioreactor, production of the enzymes of interest was low because of the long doubling time $\left(t_{\mathrm{d}}\right)$ of Sulfolobus $\left(7<t_{\mathrm{d}}<18 \mathrm{~h}\right)$ and the low expression 


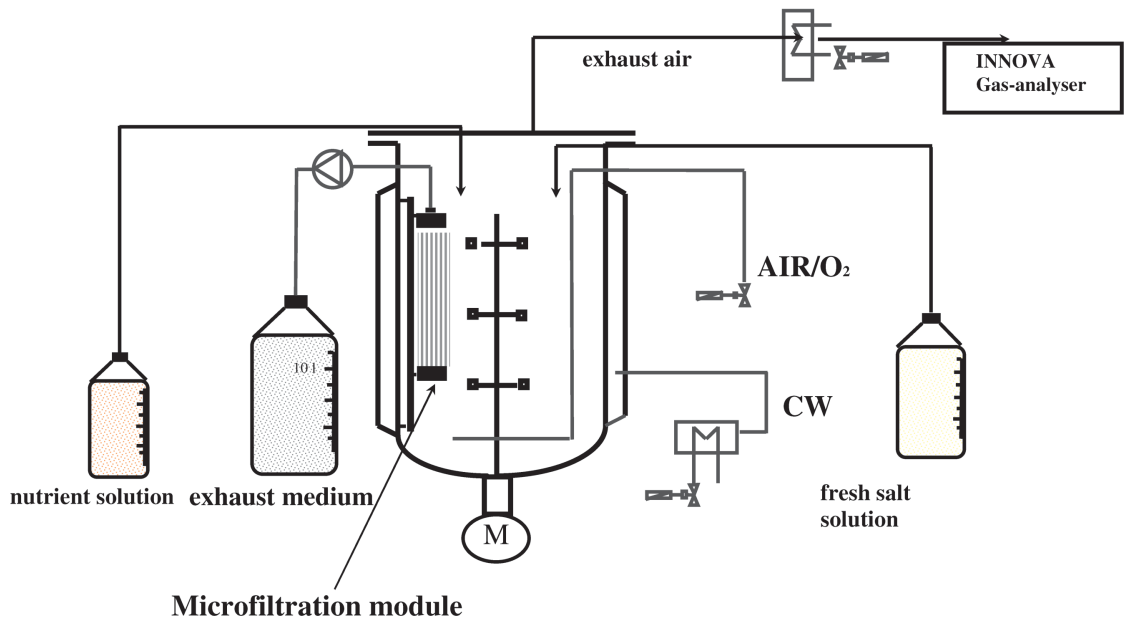

Figure 1. Schematic view of the microfiltration bioreactor (adapted from Schiraldi et al. 1999). levels of these enzymes. The most promising approach to overcoming these limitations may be to combine fermentation techniques with molecular biology techniques.

\section{Strategies for cloning and expression of archaeal enzymes and their industrial use}

Because archaeal enzymes are adapted to extreme environments, they are unusually stable. They are therefore suitable candidates for applications in industrial processes that are performed under harsh conditions, such as high temperatures or in the presence of organic solvents or high ionic strength. For the same reasons, they are also ideal model molecules for investigations aimed at elucidating the mechanisms of chemicophysical stability of proteins. Biologists already use the extremophilic enzyme Taq polymerase from Thermus aquaticus. In addition to the isolation of new enzymes, the spectrum of available enzyme capabilities could be expanded by random mutagenesis and directed evolution.

Genes encoding several enzymes from extremophiles have been cloned in mesophilic hosts, with the objective of overproducing the enzyme and altering its properties to suit commercial applications (see review by Ciaramella et al. 1995). Escherichia coli, Bacillus subtilis and yeasts have been used successfully as mesophilic hosts for several archaeal genes (Cannio et al. 1994, Moracci et al. 1994, Ito 1997, Jorgensen et al. 1997, Walsh et al. 1998, Miura et al. 1999, Niehaus et al. 1999, Duffner et al. 2000, Lim 2001).

The expression system has to be chosen based on the intended use of the expressed protein. To obtain a sufficient amount of a recombinant enzyme for basic characterization, E. coli expression is recommended, because this host is easily grown in the laboratory and the vectors are well characterized. Expression in yeasts has advantages for large-scale industrial production. Furthermore, because yeast is a "generally recognized as safe" organism, it represents an ideal pilot system for the production of enzymes for the food technology industry.

Recombinant enzymes can be obtained by cloning and expressing a synthetic gene. Fusi et al. (1995) reported the ex- pression of $\mathrm{P} 2$ ribonuclease from $S$. solfataricus in which the codon of the gene was modified to include those triplets that are widely used in E. coli cells to enhance protein expression. This modification was achieved by reverse translation of the amino acid sequence into a degenerate nucleotide sequence and synthesis by PCR amplification of overlapping primers.

To overcome the limitations of different codon usage for heterologous expression of archaeal enzymes, Purcarea et al. (2001) successfully cloned and expressed in E. coli a carbamoyl phosphatase synthetase (CPSase) from Pyrococcus abyssi. Overexpression of the CPSase gene was achieved by cotransformation of the host cells with a plasmid encoding tRNA synthetases for low-frequency $E$. coli codons. Ishida et al. (1997) were able to obtain efficient production of a thermophilic 3-isopropylmalate dehydrogenase with a GC-rich coding gene in $E$. coli, by providing a leader open reading frame. De Pascale et al. (2001) have cloned and expressed in E. coli (Rb791) genes encoding the trehalosyl dextrin forming enzyme (TDFE) and the trehalose-forming enzyme (TFE) of S. solfataricus MT4. More recently de Pascale et al. (2002) fused TFE and TDFE coding sequences to obtain a new chimeric protein that converts dextrins to trehalose at high temperature $\left(75^{\circ} \mathrm{C}\right)$ by sequential enzymatic steps. Gene fusion was carried out so that the $\mathrm{C}$-terminus of TFE, modified by the substitution of the stop codon with a Gly residue, was in frame with the N-terminus of TDFE. A linker was designed to facilitate recombinant DNA construction without deleting amino acids of either protein moiety, resulting in the insertion of the four amino acids Ser-Gly-Ser-Gly.

To facilitate biochemical characterization of unusual archaeal enzymes, production can be increased by using extremophilic microorganisms as hosts for autologous gene expression (Gardner et al. 1999). For Methanococcus species, integrative and shuttle vectors have been developed to overexpress specific enzymes with complex prosthetic groups that are inactive if expressed in E. coli (Gardner et al. 1999). It has also been tested as a host for heterologous proteins such as $\beta$-galactosidase from E. coli. 
The well-characterized E. coli model has greatly facilitated the development of molecular genetic techniques, e.g., genetic markers and gene transfer, in halophilic members of the Archaea (Holmes 1990, Holmes et al. 1991). The finding that Halomonas meridiana and H. elongata can secrete the thermostable $\alpha$-amylase from Bacillus licheniformis indicates that members of the Halomonas genus could be good candidates as cell factories for producing heterologous extracellular enzymes (Coronado et al. 2000, Frillings et al. 2000). Molecular tools for thermophilic archaea are still being developed because some of the tools developed for bacterial systems do not function in these archaeal systems (Keeling et al. 1994, Keeling and Doolittle 1995).

Genetic elements such as viruses and plasmids represent powerful tools with which to elucidate the molecular genetics of the Archaea. Moreover, new expression vectors can be obtained by manipulating existing elements. Of these, the most interesting are the genetic systems that work in multiple microorganisms. Cannio et al. (1998) constructed a shuttle vector, pEXSs, based on a Sulfolobus shibatae natural virus and an E. coli plasmid. The plasmid is able to transform and can be stably maintained in both $S$. solfataricus and E. coli, because it contains the SSV1 viral autonomously replicating sequence (ARS) (Palm et al. 1991), the pGEM5Zf(-) E. coli plasmid sequence and an antibiotic resistance gene marker for $S$. solfataricus, obtained by selection of a suitable mutant of the hygromycin phosphotransferase gene derived from E. coli (Gritz and Davies 1983). The same group also explored the feasibility of using $S$. solfataricus as a host for a mesophilic protein, hygromycin B phosphotransferase (hph) from E. coli. The hph protein was isolated by directed evolution at $75^{\circ} \mathrm{C}$, using a library of random mutant versions of the $h p h$ gene (Cannio et al. 2001). Use of the pEXSs shuttle vector allowed selection of a mutant version of the $h p h$ gene that contained two point mutations, but remained correctly folded and functional like the wild-type protein. Moreover, the construct was highly stable in more thermophilic strains at temperatures from 75 to $82{ }^{\circ} \mathrm{C}$, and hence is expected to be a good candidate as a genetic marker at even higher temperatures following further thermoadaptation (Cannio et al. 2001).

Another vector (pKMSD48) containing both SSV1 and pBluescript DNA is completely stable in both E. coli and S. solfataricus (Stedman et al. 1999). Unlike other shuttle vectors, pKMSD48 is stable in $E$. coli even at high copy numbers. Moreover, because its promoter can be controlled by UV irradiation, it can be used for in vivo overexpression of genes in S. solfataricus (Stedman et al. 1999). Although these emerging genetic engineering tools may have no direct industrial application, they will play a central role in the development of methods for the large-scale production of archaeal enzymes with potential applications in industry.

The method chosen to express an extremophilic enzyme needs to take into account the downstream processes used for enzyme purification. The major findings of studies on the cloning and expression of archaeal enzymes can be summarized as follows. (1) Archaea utilize the universal genetic code and their genes are translated by Eukarya and Bacteria. (2) The expression product maintains its natural properties including its thermophilicity and thermostability. (3) The rigid structure of thermophilic proteins at low temperature appears to prevent their degradation by host proteases, leading to an accumulation of recombinant enzyme. Recombinant extremophile enzymes are generally inactive under optimal host growth conditions, and the difference in observed biomass between different recombinants may be explained by specific interference in the replication cycle of the host by the heterologous gene expressed. (4) Thermostable enzymes can easily be purified from mesophilic protein contaminants by sequential thermal precipitation steps. After thermal denaturation, the only remaining enzymatic activity is that of the thermophilic protein expressed, which generally has a purity sufficient for industrial applications (Rossi and De Rosa 1994, Schiraldi et al. 2001).

Genetic engineering techniques are valuable tools for creating novel biocatalysts that can improve bioprocesses and facilitate the realization of innovative biotransformations. Molecular biology has the potential both to overcome the limitations on enzyme availability and to design new biocatalysts specific to a particular industrial purpose. We have proposed industrial applications for several recombinant archaeal enzymes. New industrial uses of natural and recombinant archaeal enzymes will depend on the coupling of genetic strategies and bioreactor design.

\section{Industrial potential of archaeal enzymes and metabolites}

Most of the archaeal bioproducts and bioprocesses that have been developed in industry so far are based on the unconventional properties of archaeal biomasses or of their enzymes and metabolites. Here we describe several promising applications that have been developed in the past decade, and highlight the few applications that have already reached the market.

\section{Biotechnological applications of archaeal biomasses}

Despite the potential of microorganisms from the domain Archaea, their industrial application has not been exploited, except in microbiological waste treatment processes (Kandler 1986). Biological methanogenesis is applied to the anaerobic treatment of sewage sludge, and agricultural, municipal and industrial wastes, where the maintenance of a desired methanogenic flora is achieved by innoculation. Methanogens are a taxonomically and phylogenetically diverse group of microorganisms that obtain energy for growth from the reaction leading to methane production. Methanogens use only a small number of compounds, $\mathrm{H}_{2}$ or one-carbon atom compounds, and this specialization makes them dependent on other organisms for a supply of substrates in most anaerobic environments (Boone et al. 1993).

Many bioreactor configurations have been exploited to increase the efficiency of anaerobic digestion, such as the rotating biological contactor, the anaerobic baffle reactor and the upflow anaerobic sludge blanket reactor, and several largescale plants are in operation (Rehm and Reed 1999). Recently, 
a methanogenic process has been established on a lab-scale for the anaerobic digestion of the organic fraction of municipal gray-waste based on a mixed archaeal population; the reactors have been fed daily and held in steady state for over 2 years (Scherer et al. 2000). These examples illustrate the potential for coupling waste treatment processes to biogas production, thereby recovering energy from an unavoidable process.

Halophilic archaea have also been evaluated for bioremediation in harsh environments, for the degradation of organic pollutants and in the treatment of concentrated textile waste waters, particularly the first dye bath liquor from the dying process, which contains a high salt load (Margesin and Schinner 2001). Biosurfactant-producing halophilic bacteria can play a significant role in the accelerated remediation of oil-polluted saline environments. Banat et al. (2000) obtained encouraging results for hydrocarbon pollution control at marine sites that represent self-sufficient systems. Lovley (2001) examined the degradation of hydrocarbons by archaeal microbes under anoxic conditions. Sulfate-reducing microorganisms belonging to the domain Archaea have been isolated for their capacity to degrade alkanes anaerobically. In aquatic sediments, the anaerobic oxidation of methane with sulfate as electron acceptor has been reported and is assumed to involve the reversal of methanogenesis catalyzed by archaea with the scavenging of an electron-carrying metabolite by sulfate-reducing bacteria (Sporman and Widdel 2000).

Because the application of acidophiles in bioreactor mineral processing has been reviewed recently by Norris et al. (2000), it will be mentioned only briefly here. Several industrial applications of the Crenarcheota are related to their unique sulfur metabolism. A variety of mineral sulfide-oxidizing thermophilic archaea have been isolated from both natural and industrial environments. These microorganisms have gained attention because of their potential in the extraction of metals from sulfide ores that are recalcitrant to dissolution (Norris 1990). Comparison of chalcopyrite oxidation by mesophiles, thermophiles and thermoacidophilic archaea showed that extraction efficiency increased proportionally with increasing temperature up to $80{ }^{\circ} \mathrm{C}$ (Norris and Owen 1993). Sulfolobus metallicus has been exploited for mineral biomining: in a pilot-scale bioreactor, it tolerated copper concentrations of $40 \mathrm{~g} \mathrm{l}^{-1}$ (Norris et al. 2000). The subdivision of thermoacidophiles into major phylogenetic groups is noteworthy, because it reflects the varied potential of strains for efficient mineral sulfide oxidation. Also related to the unique characteristics of the sulfur metabolism of archaea is the application of P. furiosus in the recycling of tire rubber by desulfurization and subsequent vulcanization reported by Bredberg et al. (2001). Ethanol-leached cryo-ground tire rubber treated with $P$. furiosus for 10 days was vulcanized together with virgin rubber, leading to a product with good mechanical properties.

\section{Archaeal enzymes of biotechnological interest}

In addition to the potential uses of archaeal biomasses, natural and modified archaeal enzymes also present huge possibilities for industrial applications. The biotechnological value of these enzymes is related not only to their direct applications, but also to the knowledge acquired from molecular sequences and crystallographic studies. Such knowledge will permit the redesign of conventional enzymes for use as biocatalysts in harsh industrial conditions. Widespread use of DNA polymerases from hyperthermophilic archaea may portend future common use of extremophile enzymes in biotechnology, although none of the novel enzymes from these microorganisms has yet achieved significant industrial application because of difficulties encountered in their large-scale production. Efforts to resolve or ameliorate these difficulties are likely in the near future (Cowan et al. 1992).

Many archaeal enzymes involved in carbohydrate metabolism, particularly those from the glycosyl hydrolase family, are of special interest to the industrial biotechnology sector. The starch processing industry, which converts starch into more valuable products such as dextrins, glucose, fructose and trehalose, can profit from the exploitation of thermostable enzymes. In all starch processing conversions, high temperatures are required to liquefy starch and make it accessible to enzymatic attack. Enzymes from mesophilic organisms are currently employed in these processes, but this is likely to change in the near future when the advantages of the integrated utilization of amylases, pullulanases and $\alpha$-glucosidases recently isolated from hyperthermophilic sources are harnessed (Sunna et al. 1997, Di Lernia et al. 1998, Miura et al. 1999, Leveque et al. 2000, Bertoldo and Antranikian 2001, Martino et al. 2001, Savchenko et al. 2001). Similarly, an $\alpha$-amylase produced extracellularly by the haloalkaliphilic archaeon Natronococcus sp. strain Ah-36 awaits industrial exploitation. The enzyme exhibits maximal activity at $55^{\circ} \mathrm{C}, \mathrm{pH} 8.7$ and $2.5 \mathrm{M}$ $\mathrm{NaCl}$ and hydrolyzes soluble starch, amylose, amylopectin and also glycogen, producing mainly maltotriose, with glucose and maltose as side products in negligible amounts (Kobayashi et al. 1994). Most of the known archaeal pullulanases are Type II enzymes: they attack the $\alpha-1,6$ glycosidic linkage in pullulan, producing maltotriose or, by $\alpha-1,4$ glycosidic linkage, panose and isopanose, but they are inhibited by cyclodextrins. However, a Type II archaeal pullulanase with fairly broad substrate specificity was recently detected in crude cell extracts of Desulfurococcus mucosus and was successfully cloned in Bacillus subtilis (Duffner et al. 2000). The discovery of this thermostable debranching enzyme (maximal activity at $85^{\circ} \mathrm{C}$ ) could deliver enormous benefit to the starch bioconversion process when applied in the saccharification step.

Another promising application of hyperthermophilic archaeal enzymes is in trehalose production. Trehalose, a non-reducing $\alpha$-1,1-diglucosyl disaccharide, has been shown to stabilize enzymes, antibodies, vaccines and hormones, and also has a wide variety of applications in food preparations as a preservative as well as a moisture retainer (Arguelles 2000, Guo et al. 2000, Simola et al. 2000). Currently, trehalose production is performed at $45^{\circ} \mathrm{C}$ by the sequential action of two enzymes from the mesophilic bacterium Arthrobacter sp. Q36, namely the trehalosyl dextrin forming enzyme, which converts a dextrin to the corresponding trehalosyldextrin, and the trehalose-forming enzyme, which further transforms the 
trehalosyldextrin to trehalose and a low molecular weight dextrin. The alternate action of these enzymes permits the total conversion of dextrins to trehalose. The use of thermophilic enzymes in this process would represent an improvement by eliminating problems associated with viscosity and sterility. The trehalose biosynthetic pathway was found in the archaeal enzymatic patrimony of Sulfolobales (Kobayashi et al. 1996, Di Lernia et al. 1998). These enzymes were cloned and expressed with high yield in E. coli Rb-791 (de Pascale et al. 2001), and the recombinant strains were grown at high density in a microfiltration bioreactor (Schiraldi et al. 2001). To test whether these biocatalysts could be used in an industrial setting, we assembled a plug flow reactor containing recombinant $E$. coli cells expressing the necessary enzymatic activities. Trehalose was successfully produced from dextrins at $75{ }^{\circ} \mathrm{C}$ in a continuous system, with a final conversion of 90\% (Di Lernia et al. 2001).

Another recently isolated enzyme, cyclomaltodextrin glucanotransferase, from the newly isolated hyperthermophilic archaeon Thermococcus sp. (Tachibana et al. 1999), shows optimum starch degrading activity and cyclodextrin synthesis at temperatures above $90{ }^{\circ} \mathrm{C}$. Thus, it could enhance the starch bioconversion process by lowering the viscosity and reducing contamination. An alkaline cyclomaltodextrin glucanotransferase is already used in the industrial production of cyclodextrins. This enzyme has reduced production costs and paved the way for cyclodextrin use in large quantities in foodstuffs, chemicals and pharmaceuticals (Horikoshi 1999).

Degradation of cellulose to its monomer, glucose, can be achieved through the synergistic action of three enzymes: endoglucanases, exoglucanases and $\beta$-glucosidases. The latter two enzymes have been isolated, purified and cloned from several Sulfolobales species (Cubellis et al. 1990, Grogan 1991, Moracci et al. 1992, Nucci et al. 1993, Moracci et al. 1995) as well as from Pyrococcus furiosus (celB) (Voorhorst et al. 1995, Lebbnik et al. 2001), and Pouwels et al. (2000) compared their activity and stability. An ultra high temperature process for the enzymatic hydrolysis of lactose for the production of novel oligosaccharides was developed by Petzelbauer et al. (2000) using $\beta$-glycosidases from $S$. solfataricus and $P$. furiosus. D'Auria et al. (1996) developed a continuous cellobiose hydrolysis bioreactor system for glucose production by immobilizing a $\beta$-glycosidase isolated from $S$. solfataricus and expressed in Saccharomyces cerevisiae. The system can be run at a high flow rate and has a high degree of conversion, productivity and operational stability (D'Auria et al. 1996).

Several other polymer-degrading enzymes isolated from archaea, such as xylanases and cellulases, could play important roles in the chemical, pharmaceutical, paper, pulp or waste treatment industries. Commercial interest in the applications of xylanases, which degrade xylans, the most abundant form of hemicellulose, is growing. Xylanases can play a key role as quality- or yield-improving agents in the food, feed, and pulp and paper industries (Viikari et al. 1994). Recently, a xylanase that is active at temperatures up to $100{ }^{\circ} \mathrm{C}$ was characterized in Thermococcus zilligii strain AN1. This enzyme can attack dif- ferent xylans but showed no activity toward carbohydrates (Uhl and Daniel 1999). A detailed review of xylanases, including those isolated from hyperthermophiles, is presented by Bergquist et al. (2001). Among the few cellulase activities found in the domain Archaea, the most interesting include the cellulase CelS from $S$. solfataricus (Limauro et al. 2001) and a $\beta$-endoglucanase from $P$. furiosus (Cady et al. 2001).

Hyperthermophilic proteases are important as degrading agents in detergent formulations (Schumacher et al. 2001). Proteases and proteasomes play a key role in the cellular metabolism of archaea. The adaptation of these microorganisms to extreme habitats is mediated by an interplay between protein folding and hydrolysis (Iida et al. 2000, Maupin-Furlow et al. 2000, de Vos et al. 2001, Wadsworth et al. 2001). Lipases and esterases from Archaeoglobus fulgidus (Manco et al. 2000) and Sulfolobus shibatae (Huddleston et al. 1995) have been purified and characterized, and are also of interest in detergent formulations and the dairy industry. Hydrolases and isomerases from extremely halophilic archaea have potential applications in several biotransformations in the production of food supplements; the microorganisms themselves can be exploited in the production of fermented food (Margesin and Schinner 2001).

\section{Archaeal metabolites for biotechnology}

Some archaeal metabolites, such as proteins, osmotically active substances (so-called compatible solutes), exopolysaccharides and special lipids have potential industrial applications. Halophilic archaea offer a multitude of actual or potential biotechnological applications. Certain strains contain membrane-bound retinal pigments, bacteriorhodopsin (BR) and halorhodopsin, which enable microorganisms to use light energy to drive bioenergetic processes (Oren 1994, Lanyi 1995). The thermodynamic and photochemical stability of BR has led to many uses in technical applications, such as in holography, spatial light modulators, artificial retina, volumetric and associative optical memories. Bacteriorhodopsin, isolated from Halobacterium salinarum, is currently being commercialized by COBEL (Barcelona, Spain) and Munich Innovative Biomaterials (Munich, Germany) (Margesin and Shinner 2001). Furthermore, BR can be exploited for the renewal of biochemical energy such as the back conversion of ADP to ATP. A device based on BR and ATP synthase has been developed and patented (Saito et al. 1992).

Halophilic bacteria produce compatible solutes that maintain a positive water balance in the cell and are compatible with the cellular metabolism. These compatible solutes are excellent stabilizers for biomolecules (da Costa et al. 1998, Welsh 2000, Santos and da Costa 2001). Ectoine and derivatives have been patented as moisturizers in cosmetics (Montitsche et al. 2000), although the most promising application may be as stabilizers in the polymerase chain reaction (Sauer and Galinski 1998). Compatible solutes produced by halophilic archaea include mannosylglycerate (MG) and diglycerol phosphate, and they have also beeen identified in P. furiosus, $P$. woesei and Archaeoglobus fulgidus. The stabilizing effect of MG on several enzymes subjected to heating or 
freeze-drying was superior to that of other stabilizers (Lamosa et al. 2000).

Archaeal lipids are unique in relation to their topology and function in archaeal membranes and represent an important evolutionary marker within the Archaea and among the Eukaryal, Bacterial and Archaeal domains. This uniqueness has boosted interest in the biotechnological applications of such compounds. They are an excellent source for the formation of liposomes with remarkable thermostability and tightness against solute leakage (Gambacorta et al. 1995). Both in vitro and in vivo studies indicate that archaeosomes (liposomes from archaeal lipids) are safe, and their stability and tissue distribution profiles, as well as the adjuvant activity of archaeosome formulations, indicate that they may offer a superior alternative for several biotechnological applications, including delivery systems for drugs, genes or cancer imaging agents (Patel and Sprott 1999). Novel patented ether lipids were obtained from the extreme halophile Halobacterium cutirubrum. Homogeneous liposomes have also been obtained by extruding an emulsion of the total polar ether lipid fraction through membranes of various pore sizes. Liposomes produced in this way are resistant to attack by phospholipase and can be stored for 60 days in air (Choquet et al. 1999). Archaeal lipids have been proposed as monomers for bioelectronics for several reasons, the most important being that their bipolar tetraether structure offers novel opportunities for protein-lipid interactions, which are of interest for the assembly of electronic devices based on redox proteins or enzymes (see review by De Rosa et al. 1994).

\section{Concluding remarks}

Many microorganisms have been isolated from the domain Archaea, and among the archaeal enzymes that have been purified and characterized, several show potential for industrial uses. Archaeal metabolites suitable for industrial applications have also been found. However, biotechnological processes based on these archaeal tools remain limited, despite the extensive recent literature suggesting possible novel bioprocesses and demonstrating the applicability of several biomolecules of archaeal origin in the biotechnology industry. The slow incorporation of archaeal tools by industry can be ascribed mainly to the difficulties associated with the development of large-scale processes for the production of archaeal biomasses, proteins and metabolites. In addition, the expression level of archaeal enzymes is low and the purification procedures for obtaining biocatalysts are difficult and expensive.

Genome sequencing should help to overcome many of these difficulties. At least for archaeal enzyme production, cloning into an easy-to-grow mesophilic host may be the preferred method because it simplifies downstream processing. The separation of host proteins from the enzyme of interest can easily be achieved by exploiting differences in stability under extreme conditions. Strategies that combine molecular biology techniques and customized bioprocess design could greatly improve the yields of archaeal bioproducts, resulting in major cost savings, thereby enabling industrial applications of these unique biomaterials.

\section{References}

Arguelles, J.C. 2000. Physiological roles of trehalose in bacteria and yeasts: a comparative analysis. Arch. Microbiol. 174:217-224.

Banat, I.M., R.S. Makkar and S.S. Cameotra. 2000. Potential commercial applications of microbial surfactants. Appl. Microbiol. Biotechnol. 53:495-508.

Bergquist, P.L., M.D. Gibbs, D.D. Morris, D.R. Thompson, A.M. Uhl and R.M. Daniel. 2001. Hyperthermophilic xylanases. Methods Enzymol. 330:301-319.

Bertoldo, C. and G. Antranikian. 2001. Amylolytic enzymes from hyperthermophiles. Methods Enzymol. 330:269-289.

Boone, D.R., W.B. Whitman and P. Rouviere. 1993. Diversity and taxonomy of methanogens. In Methanogenesis: Ecology, Physiology, Biochemistry, and Genetics. Ed. J.G. Ferry. Chapman and Hall, London, pp 35-80.

Bredberg, K., J. Persson, M. Christiansson, B. Stenberg and O. Holst. 2001. Anaerobic desulfurization of ground rubber with the thermophilic archaeon Pyrococcus furiosus-a new method for rubber recycling. Appl. Microbiol. Biotechnol. 55:43-48.

Bult, C.J., O. White, G.J. Olsen, et al. 1996. Complete genome sequence of the methanogenic archaeon, Methanococcus jannaschii. Science 273:1058-1073.

Cady, S.G., M.W. Bauer, W. Callen, M.A. Snead, E.J. Mathur, J.M. Short and R.M. Kelly. 2001. Beta-endoglucanase from Pyrococcus furiosus. Methods Enzymol. 330:346-354.

Cannio, R., P. Contursi, M. Rossi and S. Bartolucci. 1998. An autonomously replicating transforming vector for Sulfolobus solfataricus. J. Bacteriol. 180:3237-3240.

Cannio, R., P. Contursi, M. Rossi and S. Bartolucci. 2001. Thermoadaptation of a mesophilic hygromycin B phosphotransferase by directed evolution in hyperthermophilic archaea: selection of a stable genetic marker for DNA transfer into Sulfolobus solfataricus. Extremophiles 5:153-159.

Cannio, R., D. de Pascale, M. Rossi and S. Bartolucci. 1994. Gene expression of a thermostable beta-galactosidase in mammalian cells and its application in assays of eukaryotic promoter activity. Biotechnol. Appl. Biochem. 19:233-244.

Choquet, C.G., G.B. Patel, I. Ekiel and G.D. Sprott. 1999. Formation of stable liposomes from lipid extracts of archaeobacteria. Patent US5989587.1999 November 23.

Ciaramella, M., R. Cannio, M. Moracci, F.M. Pisani and M. Rossi. 1995. Molecular biology of extremophiles. World J. Microbiol. Biotechnol. 11:71-84.

Coronado, M.J., C. Vargas, E. Mellado, G. Tegos, C. Drainas, J.J. Nieto and A. Ventosa. 2000. The alpha-amylase gene $a m y H$ of the moderate halophile Halomonas meridiana: cloning and molecular characterization. Microbiology 146:861-868.

Cowan, D.A. 1992. Enzymes from thermophilic Archaeabacteria: current and future application in biotechnology. In The Archaebacteria: Biochemistry and Biotechnology (Biochem. Soc. Symp. 58). Eds. J. Danson, D.W. Hough and G.G. Lunt. Portland Press, London, pp 149-169.

Cubellis, M.V., C. Rozzo, P. Montecucchi and M. Rossi. 1990. Isolation and sequencing of a new $\beta$-galactosidase encoding archaebacterial gene. Gene 94:89-94.

D’Auria, S., F. Pellino, F. La Cara, R. Barone, M. Rossi and R. Nucci. 1996. Immobilization on chitosan of a thermophilic $\beta$-glycosidase expressed in Saccharomyces cerevisiae. Appl. Biochem. Biotechnol. 61:157-166. 
da Costa, M.S., H. Santos and E.A. Galinski. 1998. An overview of the role and diversity of compatible solutes in Bacteria and Archaea. Adv. Biochem. Eng. Biotechnol. 61:117-153.

de Pascale, D., M.P. Sasso, I. Di Lernia, A. Di Lazzaro, A. Furia, M. Cartenì Farina, M. Rossi and M. De Rosa. 2001. Recombinant thermophilic enzymes for trehalose and trehalosyl dextrins production. J. Mol. Catal. B Enzym. 11:777-786.

De Rosa, M., A. Morana, A. Riccio, A. Gambacorta, A. Trincone and O. Incani. 1994. Lipids of the Archaea: a new tool for bioelectronics. Biosens. Bioelectron. 9:669-675.

De Vos, W.M., W.G. Voorhorst, M. Dijkgraaf, L.D. Kluskens, J. van der Oost and R.J. Siezen. 2001. Purification, characterization, and molecular modeling of pyrolysin and other extracellular thermostable serine proteases from hyperthermophilic microorganisms. Methods Enzymol. 330:383-393.

Di Lernia, I., A. Morana, A. Ottobrino, S. Fusco, M. Rossi and M. De Rosa. 1998. Enzymes from Sulfolobus shibatae for the production of trehalose and glucose from starch. Extremophiles 2:409-416.

Di Lernia, I., C. Schiraldi, M. Generoso and M. De Rosa. 2001. Trehalose production at high temperature exploiting an immobilized cell bioreactor. Extremophiles, DOI 10.1007/S00792-0010262-3.

Duffaud, G.D., O.B. d'Hennezel, A.S. Peek, A.L. Reysenbach and R.M. Kelly. 1998. Isolation and characterization of Thermococcus barossi, sp. nov., a hyperthermophilic archaeon isolated from a hydrothermal vent flange formation. Syst. Appl. Microbiol. 21: 40-49.

Duffner, F., C. Bertoldo, J.T. Andersen, K. Wagner and G. Antranikian. 2000. A new thermoactive pullulanase from Desulfurococcus mucosus: cloning, sequencing, purification, and characterization of the recombinant enzyme after expression in Bacillus subtilis. J. Bacteriol. 182:6331-6338.

Frillings, S., A. Linden, F. Niehaus, C. Vargas, J.J. Nieto, A. Ventosa, G. Antranikian and C. Drainas. 2000. Cloning and expression of alpha-amylase from the hyperthermophilic archaeon Pyrococcus woesei in the moderately halophilic bacterium Halomonas elongata. J. Appl. Microbiol. 88:495-503.

Fusi, P., M. Grisa, E. Mombelli, R. Consonni, P. Tortora and M. Vanoni. 1995. Expression of a synthetic gene encoding P2 ribonuclease from the extreme thermoacidophilic archaebacterium Sulfolobus solfataricus in mesophylic hosts. Gene 154:99-103.

Galagan, J.E., C. Nusbaum, A. Roy et al. 2002. The genome of M. acetivorans reveals extensive metabolic and physiological diversity. Genome Res. 12:532-542.

Gambacorta, A., A. Ghiozzi and M. De Rosa. 1995. Archaeal lipids and their biotechnological applications. World J. Microbiol. Biotechnol. 11:115-132.

Gardner, W.L. and W.B. Whitman. 1999. Expression vectors for Methanococcus maripaludis. Overexpression of acetohydroxyacid synthase and $\beta$-galactosidase. Genetics 152:1439-1447.

Godfroy, A., N.D. Raven and R.J. Sharp. 2000. Physiology and continuous culture of the hyperthermophilic deep-sea vent archaeon Pyrococcus abyssi ST549. FEMS Microbiol. Lett. 186:127-132.

Graham, D.E., R. Overbeek, G.J. Olsen and C.R. Woese. 2000. An archaeal genomic signature. Proc. Natl. Acad. Sci. 97:3304-3308.

Gritz, L. and J. Davies. 1983. Plasmid-encoded hygromycin B resistance: the sequence of hygromycin B phosphotransferase gene and its expression in Escherichia coli and Saccharomyces cerevisiae. Gene 25:179-188.

Grogan, D.W. 1991. Evidence of $\beta$-galactosidase of Sulfolobus solfataricus is only one of several activities of a thermostable $\beta$-D-glycosidase. Appl. Environ. Microbiol. 57:1644-1649.
Guo, N., I. Puhlev, D.R. Brown, J. Mansbridge and F. Levine. 2000. Trehalose expression confers desiccation tolerance on human cells. Nat. Biotechnol. 18:168-171.

Haney, P.J., J.H. Badger, G.L. Buldak, C.I. Reich, C.R. Woese and G.J. Olsen. 1999. Thermal adaptation analyzed by comparison of protein sequences from mesophilic and extremely thermophilic Methanococcus species. Proc. Natl. Acad. Sci. 96:3578-3583.

Herbert, R.A. 1992. A perspective on the biotechnological potential of extremophiles. TIBTECH 10:395-401.

Hezayen, F.F., B.H. Rehm, R. Eberhardt and A. Steinbüchel. 2000. Polymer production by two newly isolated extremely halophilic archaea: application of a novel corrosion-resistant bioreactor. Appl. Microbiol. Biotechnol. 54:319-325.

Holmes, M.L. and M.L. Dyall-Smith. 1990. A plasmid vector with a selectable marker for halophilic archaebacteria. J. Bacteriol. 172: $756-761$.

Holmes, M.L., S.D. Nuttal and M.L. Dyall-Smith. 1991. Construction and use of halobacterial shuttle vectors and further studies on Haloferax DNA gyrase. J. Bacteriol. 173:3807-3813.

Horikoshi, K. 1999. Alkaliphiles: some applications of their products for biotechnology. Microbiol. Mol. Biol. Rev. 63:735-750.

Hough, D.W. and M.J. Danson. 1999. Extremozymes. Curr. Opin. Chem. Biol. 3:39-46.

Huddleston, S., C.A. Yallop and B.M. Charalambous. 1995. The identification and partial characterization of a novel inducible extracellular thermostable esterase from the archaeon Sulfolobus shibatae. Biochem. Biophys. Res. Commun. 216:495-500.

Iida, T., T. Iwabuchi, A. Ideno, S. Suzuki and T. Maruyama. 2000. FK506-binding protein-type peptidyl-prolyl cis-trans isomerase from a halophilic archaeum, Halobacterium cutirubrum. Gene 256:319-326.

Ishida, M., M. Yoshida and T. Oshima. 1997. Highly efficient production of enzymes of an extreme thermophile, Thermus thermophilus: a practical method to overexpress GC- rich genes in Escherichia coli. Extremophiles 1:157-162.

Ito, S. 1997. Alkaline cellulases from alkaliphilic Bacillus: enzymatic properties, genetics and application to detergents. Extremophiles 1:61-66.

Jorgensen, S., C.E. Vorgias and G. Antranikian. 1997. Cloning, sequencing, characterization, and expression of an extracellular alpha-amylase from the hyperthermophilic archaeon Pyrococcus furiosus in Escherichia coli and Bacillus subtilis. J. Biol. Chem. 272:16,335-16,342.

Kandler, O. and W. Zillig. 1986. Archaebacteria. Gustav Fischer Verlag, Stuttgart, $401 \mathrm{p}$.

Kawarabayasi, Y., Y. Hino, H. Horikawa et al. 1999. Complete genome sequence of an aerobic hyper-thermophilic crenarchaeon, Aeropyrum pernix K1. DNA Res. 6(2):83-101, 145-152.

Kawarabayasi, Y., Y. Hino, H. Horikawa et al. 2001. Complete genome sequence of an aerobic thermoacidophilic crenarchaeon, Sulfolobus tokodaii strain 7. DNA Res. 8(4):123-140.

Kawarabayasi, Y., M. Sawada, H. Horikawa et al. 1998. Complete sequence and gene organization of the genome of a hyperthermophilic archaebacterium, Pyrococcus horikoshii OT3. DNA Res. 5 (2):55-76.

Kawashima, T., N. Amano, H. Koike et al. 2000. Archaeal adaptation to higher temperatures revealed by genomic sequence of Thermoplasma volcanium. Proc. Natl. Acad. Sci. 97:14,257-14,262.

Keeling, P.J., R.L. Charlebois and W.F. Doolittle. 1994. Archaebacterial genomes: eubacterial form and eukaryotic content. Curr. Opin. Genet. Dev. 4:816-822. 
Keeling, P.J. and W.F. Doolittle. 1995. Archaea: narrowing the gap between prokaryotes and eukaryotes. Proc. Natl. Acad. Sci. 92: $5761-5764$.

Kelly, R.M. and J.W. Deming. 1988. Extremely thermophilic archaebacteria: biological and engineering considerations. Biotechnol. Prog. 4:47-61.

Klenk, H.P., R.A. Clayton, J.F. Tomb, et al. 1997. The complete genome sequence of the hyperthermophilic, sulphate-reducing archaeon Archaeoglobus fulgidus. Nature 390:364-370.

Kobayashi, K., M. Kato, Y. Miura, M. Kettoku T. Komeda and A. Iwamatsu. 1996. Gene cloning and expression of new trehaloseproducing enzymes from the hyperthermophilic archaeon Sulfolobus solfataricus KM1. Biosci. Biotechnol. Biochem. 60: 1882-1885.

Kobayashi, T., H. Hanai, R. Aono, K. Horikoshi and T. Kudo. 1994. Cloning, expression and nucleotide sequence of the $\alpha$-amylase gene from the haloalkaliphilic archaeon Natronococcus sp. Strain Ah-36. J. Bacteriol. 176:5131-5134.

Krahe, M., G. Antyranikian and H. Märkl. 1996. Fermentation of extremophilic microorganisms. FEMS Microbiol. Rev. 18: 271-285.

Lamosa, P., A. Burke, R. Peist, R. Huber, M.Y. Liu, G. Silva, R. Rodrigues-Pousada, J. Le Gall, C. Maycock and H. Santos. 2000. Thermostabilization of proteins by diglycerol phosphate, a new compatible solute from the hyperthermophile Archaeoglobus fulgidus. Appl. Environ. Microbiol. 66:1974-1979.

Lanyi, J.K. 1995. Bacteriorhodopsin as a model for proton pumps. Nature 75:461-463.

Lebbink, J.H., T. Kaper, S.W. Kengen, J. van der Oost and W.M. de Vos. 2001. Beta-glucosidase CelB from Pyrococcus furiosus: production by Escherichia coli, purification and in vitro evolution. Methods Enzymol. 330:364-379.

Leveque, E., B. Haye and A. Belarbi. 2000. Cloning and expression of an alpha-amylase encoding gene from the hyperthermophilic archaebacterium Thermococcus hydrothermalis and biochemical characterization of the recombinant enzyme. FEMS Microbiol. Lett. 186:67-71.

Lim, J.H., J. Choi, S.J. Han, S.H. Kim, H.Z. Hwang, D.K. Jin, B.Y. Ahn and Y.S. Han. 2001. Molecular cloning and characterization of the thermostable DNA ligase from Aquifex pyrophilus, a hyperthermophilic bacterium. Extremophiles 5:161-168.

Limauro, D., R. Cannio, G. Fiorentino, M. Rossi and S. Bartolucci. 2001. Identification and molecular characterization of an endoglucanase gene, celS, from the extremely thermophilic archaeon Sulfolobus solfataricus. Extremophiles 5:213-219.

Lovley, D.R. 2001. Bioremediation: Anaerobes to the rescue. Science 239:1444-1446.

Madigan, M.T. and B.L. Marrs. 1997. Extremophiles. Sci. Am. 276: 82-87.

Manco, G., E. Giosuè, S. D'Auria, P. Herman, G. Carrera and M. Rossi. 2000. Cloning, overexpression and properties of a new thermophilic and thermostable esterase with sequence similarity to hormone-sensitive lipase subfamily from the archaeon Archaeoglobus fulgidus. Arch. Biochem. Biophys. 373:182-192.

Margesin, R. and F. Schinner. 2001. Potential of halotolerant and halophilic microorganisms for biotechnology. Extremophiles 5: $73-83$.

Martino, A., C. Schiraldi, S. Fusco, et al. 2001. Properties of the recombinant $\alpha$-glucosidase from Sulfolobus solfataricus in relation to starch processing. J. Mol. Cat. B. Enzym. 11:787-794.

Maupin-Furlow, J.A., H.L. Wilson, S.J. Kaczowka and M.S. Ou. 2000. Proteasomes in the Archaea: from structure to function. Front. Biosci. 5:D837-865.
Miura, Y., M. Kettoku, M. Kato, K. Kobayashi and K. Kondo. 1999. High level production of thermostable alpha-amylase from Sulfolobus solfataricus in high-cell density culture of the food yeast Candida utilis. J. Mol. Microbiol. Biotechnol. 1:129-134.

Montitsche L., H. Driller and E. Galinski. 2000. Ectoine and ectoine derivatives as moisturizers in cosmetics. Patent US060071. 2000 May 9.

Moracci, M., M. Ciaramella, R. Nucci, L.H. Pearl, I. Sanderson, A. Trincone and M. Rossi. 1994. Thermostable $\beta$-glycosidase from the extreme thermoacidophilic Archaeon Sulfolobus solfataricus. Biocatalysis 11:89-103.

Moracci, M., A. La Volpe, J.F. Pulitzer, M. Rossi and M. Ciaramella. 1992. Expression of the thermostable beta-galactosidase gene from the archaebacterium Sulfolobus solfataricus in Saccharomyces cerevisiae and characterization of a new inducible promoter for heterologous gene expression. J. Bacteriol. 174:873-882.

Moracci, M., R. Nucci, F. Febbraio, C. Vaccaro, N. Vespa, F. La Cara and M. Rossi. 1995. Expression and extensive characterization of a $\beta$-glycosidase from the extreme thermoacidophilic Archaeon Sulfolobus solfataricus. Enzyme Microb. Technol. 17:992-997.

Mukhopadhyay, B., E.F. Johnson and R.S. Wolfe. 1999. Reactor-scale cultivation of the hyperthermophilic methanarchaeon Methano- coccus jannaschii to high cell denisties. Appl. Environ. Microbiol. 65:5059-5065.

Ng, W.V., S.P. Kennedy, G.G. Mahairas et al. 2000. Genome sequence of Halobacterium species NRC-1. Proc. Natl. Acad Sci. 97: 12,176-12,181.

Niehaus, F., C. Bertoldo, M. Kahler and G. Antranikian. 1999. Extremophiles as a source of novel enzymes for industrial application. Appl. Microbiol. Biotechnol. 51:711-729.

Nordberg-Karlsson, E., O. Holst and A. Tocaj. 1999. Efficient production of truncated thermostable xylanases from Rhodothermus marinus in Escherichia coli fed-batch cultures. J. Biosci. Bioeng. 87:598-606.

Norris, P.R. 1990. Acidophilic bacteria and their activity in mineral sulfides oxidation. In Microbial Mineral Recovery. Eds. H.L. Ehrlich and C.L. Brierely. McGaw-Hill, New York, pp 3-27.

Norris, P.R. and J.P. Owen. 1993. Mineral sulfide oxidation by enrichment cultures of novel thermoacidophilic bacteria. FEMS Microbiol. Rev. 11:51-56.

Norris, P.R., N.P. Burton and N.A.M. Foulis. 2000. Acidophiles in bioreactor mineral processing. Extremophiles 4:71-76.

Nucci, R., M. Moracci, C. Vaccaro, N. Vespa and M. Rossi. 1993. Exo-glucosidase activity and substrate specificity of the $\beta$-glycosidase gene in the Archaeon Sulfolobus solfataricus. J. Bacteriol. 177:1614-1619.

Oren, A. 1994. The ecology of extremely halophilic Archaea. FEMS Microbiol. Rev. 13:415-440.

Palm, P., C. Schleper, B. Grampp, S. Yeats, P. McWilliam, W.D. Reiter and W. Zillig. 1991. Complete nucleotide sequence of the virus SSV1 of the archaebacterium Sulfolobus shibatae. Virology 185:242-250.

Park, C.B. and S.B. Lee. 1997. Constant volume fed-batch operation for high density cultivation of hyperthermophilic aerobes. Biotechnol. Tech. 11:277-281.

Park, C.B. and S.B. Lee. 1999. Cultivation of the hyperthermophilic Archaeon Sulfolobus solfataricus in low salt media. Biotechnol. Bioproc. Eng. 4:21-25.

Patel, G.B. and G.D. Sprott. 1999. Archaeobacterial ether lipid liposomes (archaeosomes) as novel vaccine and drug delivery systems. Crit. Rev. Biotechnol. 19:317-357. 
Petzelbauer, I., R. Zeleny, A. Reiter, K.D. Kulbe and B. Nidetzky. 2000. Development of an ultra-high-temperature process for the enzymatic hydrolysis of lactose. II. Oligosaccharide formation by two thermostable beta-glycosidases. Biotechnol. Bioeng. 69: 140-149.

Pouwels, J., M. Moracci, B. Cobucci-Ponzano, G. Perugino, J. van der Oost, T. Kaper, J.H. Lebbnik, W.M. de Vos, M. Ciaramella and M. Rossi. 2000. Activity and stability of hyperthermophilic enzymes: a comparative study on two archaeal $\beta$-glycosidases. Extremophiles 4:157-164.

Purcarea, C., G. Herve, R. Cunin and D.R. Evans. 2001. Cloning, expression, and structure analysis of carbamate kinase-like carbamoyl phosphate synthetase from Pyrococcus abyssi. Extremophiles 5:229-239.

Raven, N. and R.J. Sharp. 1997. Development of defined and minimal media for the growth of the hyperthermophilic archaeon Pyrococcus furiosus Vc.1. FEMS Microbiol. Lett. 146:135-141.

Raven, N., N. Ladwa, D. Cossar and R. Sharp. 1992. Continuous culture of the hyperthermophilic archaeon Pyrococcus furiosus. Appl. Microbiol. Biotechnol. 38:263-267.

Rehm, H.J., G. Reed, A. Pühler and P. Stadler. 1999. Biotechnology: Environmental processes I. Vol. 11a. 2nd Edn. Wiley, New York, pp 458-468.

Rinker, K.D. and R.M. Kelly. 2000. Effect of carbon and nitrogen sources on growth dynamics and exopolysaccharide production of the hyperthermophilic archaeon Thermococcus litoralis and bacterium Thermotoga maritima. Biotechnol. Bioeng. 69:537-547.

Rinker, K.D., C.J. Han and R.M. Kelly. 1999. Continuous culture as a tool for investigating the growth physiology of heterothrophic hyperthermophiles and extreme thermoacidophiles. J. Appl. Microbiol. 85:118S-127S.

Romano, I., V. Calandrelli, E. Pagnotta and R. Di Maso. 1992. Whey as medium for biomass production of Sulfolobus solfataricus. Biotechnol. Tech. 6:391-392.

Rossi, M. and M. De Rosa. 1994. Extremophiles in biotechnology. ECB6: Proc. 6th European Congress on Biotechnology.

Rothe, O. and M.A. Thomm. 2000. Simplified method for the cultivation of extreme anaerobic archaea based on the use of sodium sulfite as reducing agent. Extremophiles 4:247-252.

Rüdiger, A., J.C. Ogbonna and H. Märkl. 1992. Effect of gassing, agitation, substrate supplementation and dialysis on the growth of an extremely thermophilic archaeon Pyrococcus woesei. Appl. Microbiol. Biotechnol. 37:501-504.

Ruepp, A., W. Graml, M.L. Santos-Martinez, K.K. Koretke, C. Volker, H.W. Mewes, D. Frishman, S. Stocker, A.N. Lupas and W. Baumeister. 2000. The genome sequence of the thermoacidophilic scavenger Thermoplasma acidophilum. Nature 407:508-513.

Russell, N.J. 2000. Toward a molecular understanding of cold activity of enzymes from psychrophiles. Extremophiles 4:83-90.

Saito, M., T. Koyano, H. Miyamoto, K. Unibe and M. Kato. 1992. ATP synthetizing device. Patent JP4088995.

Santos, H. and M.S. da Costa. 2001. Organic solutes from thermophiles and hyperthermophiles. Methods Enzymol. 334:302-315.

Sauer, T. and E.A. Galinski. 1998. Bacterial milking: a novel bioprocess for production of compatible solutes. Biotechnol. Bioeng. 57:306-313.

Savchenko, A., C. Vielle and J.G. Zeikus. 2001. Alpha-amylases and amylopullulanase from Pyrococcus furiosus. Methods Enzymol. 330:354-363.

Scherer, P.A., G.R. Vollmer, T. Fakhouri and S. Martensen. 2000. Development of a methanogenic process to degrade exhaustively the organic fraction of municipal "grey waste" under thermophilic and hyperthermophilic conditions. Water Sci. Technol. 41(3):83-91.
Schill, N., W.M. van Gulik, R. Voisard and U. von Stickar. 1996. Continuous cultures limited by gaseous substrate: development of a simple, unstructured mathematical model and experimental verification with Methanobacterium thermoautotrophicum. Biotechnol. Bioeng. 51:645-658.

Schill, N.A., J.S. Liu and U.V. Stockar. 1999. Thermodynamic analysis of growth of Methanobacterium thermoautotrophicum. Biotechnol. Bioeng. 64:74-81.

Schiraldi, C., F. Marulli, I. Di Lernia, A. Martino and M. De Rosa. 1999. A microfiltration bioreactor to achieve high cell density in Sulfolobus solfataricus fermentation. Extremophiles 3:199-204.

Schiraldi, C., A. Martino, M. Acone, I. Di Lernia, A. Di Lazzaro, F. Marulli, M. Generoso, M. Carteni and M. De Rosa. 2000. Effective production of a thermostable $\alpha$-Glucosidase from Sulfolobus solfataricus in Escherichia coli exploiting a microfiltration bioreactor. Biotech. Bioeng. 70:670-676.

Schiraldi, C., M. Acone, M. Giuliano, I. Di Lernia, C. Maresca, M. Cartenì and M. De Rosa. 2001. Innovative fermentation strategies for the production of extremophilic enzymes. Extremophiles 5:193-198.

Schumacher, K., E. Heine and H. Hocker. 2001. Extremozymes for improving wool properties. J. Biotechnol. 89:281-288.

She, Q., R.K. Singh, F. Confalonieri, et al. 2001. The complete genome of the crenoarchaeon Sulfolobus solfataricus P2. Proc. Natl. Acad. Sci. 98:7835-7840.

Simola, M., A. Hanninen, S. Stranius and M. Makarow. 2000. Trehalose is required for conformational repair of heat-denatured proteins in the yeast endoplasmic reticulum but not for maintenance of membrane traffic functions after severe heat stress. Mol Microbiol. 37:42-53.

Slesarev, A.I., K.V. Mezhevaya, K.S. Makarova et al. 2002. The complete genome of hyperthermophile Methanopyrus kandleri AV19 and monophyly of archaeal methanogens. Proc. Natl. Acad. Sci. 99:4644-4649.

Smith, D.R., L.A. Doucette-Stamm, C. Deloughery et al. 1997. Complete genome sequence of Methanobacterium thermoautotrophicum $\Delta \mathrm{H}$ : functional analysis and comparative genomics. J. Bacteriol. 179:7135-7155.

Spormann, A.M. and F. Widdel. 2000. Metabolism of alkylbenzenes, alkenes, and other hydrocarbons in anaerobic bacteria. Biodegradation 11:85-105.

Stedman, K.M., C. Schleper, E. Rumpf and W. Zillig. 1999. Genetic requirements for the function of the archaeal virus SSV1 in Sulfolobus solfataricus: construction and testing of viral shuttle vectors. Genetics 152:1397-1405.

Sunna, A., M. Moracci, M. Rossi and G. Antranikian. 1997. Glycosyl hydrolases from hyperthermophiles. Extremophiles 1:2-13.

Tachibana, Y., A. Kuramura, N. Shirasaka, Y. Suzuki, T. Yamamoto, S. Fujiwara, M. Takagi and T. Imanaka. 1999. Purification and characterization of an extremely thermostable cyclomaltodextrin glucanotransferase from a newly isolated hyperthermophilic archaeon, a Thermococcus sp. Appl. Environ. Microbiol. 65: 1991-1997.

Tsao, J.H., M.K. Kaneshiro, S. Yu and D.S. Clark. 1994. Continuous culture of Methanococcus jannaschii, an extremely thermophilic methanogen. Biotechnol. Bioeng. 43:258-261.

Uhl, A.M. and R.M. Daniel. 1999. The first description of an archaeal hemicellulase: the xylanase from Thermococcus zilligii AN1. Extremophiles 3:263-267.

Van der Oost, J., M. Ciaramella, M. Moracci, F.M. Pisani, M. Rossi and W.M. de Vos. 1998. Molecular biology of hyperthermophilic archaea. Adv. Biochem. Eng. Biotechnol. 61:87-115. 
Viikari, L., A. Kantelinen, J. Sundquist and M. Linko. 1994. Xylanases in bleaching: from an idea to the industry. FEMS Microbiol. Rev. 13:335-350.

Voorhorst, W.G., R.I. Eggen, E.J. Luesink and W.M. de Vos. 1995. Characterization of the $c e l \mathrm{~B}$ gene coding for beta-glucosidase from the hyperthermophilic archaeon Pyrococcus furiosus and its expression and site-directed mutation in Escherichia coli. J. Bacteriol. 177:7105-7111.

Walsh, D.J., M.D. Gibbs and P.L. Bergquist. 1998. Expression and secretion of a xylanase from the extreme thermophile, Thermotoga strain FjSS3B.1, in Kluyveromyces lactis. Extremophiles 2:9-14.
Welsh, D.T. 2000. Ecological significance of compatible solute accumulation by micro-organisms: from single cells to global climate. FEMS Microbiol. Rev. 24:263-290.

Wadsworth, R.I. and M.F. White. 2001. Identification and properties of the crenarchaeal single stranded DNA binding protein from Sulfolobus solfataricus. Nucleic Acid Res. 29:914-920.

Woese, C.R. and G.E. Fox. 1977. Phylogenetic structure of the prokaryotic domain: the primary kingdoms. Proc. Natl. Acad. Sci. 74: 5088-5090. 

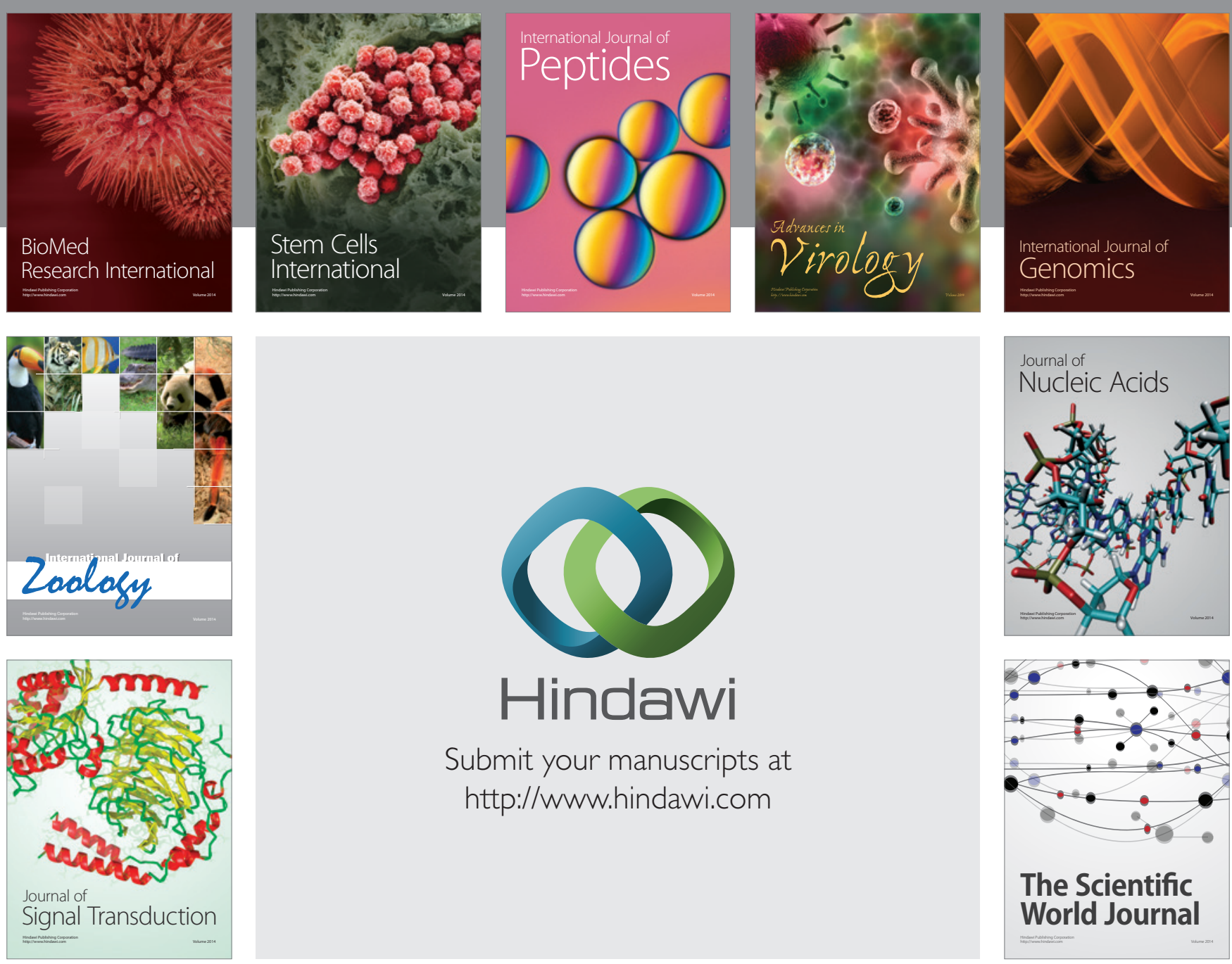

Submit your manuscripts at

http://www.hindawi.com
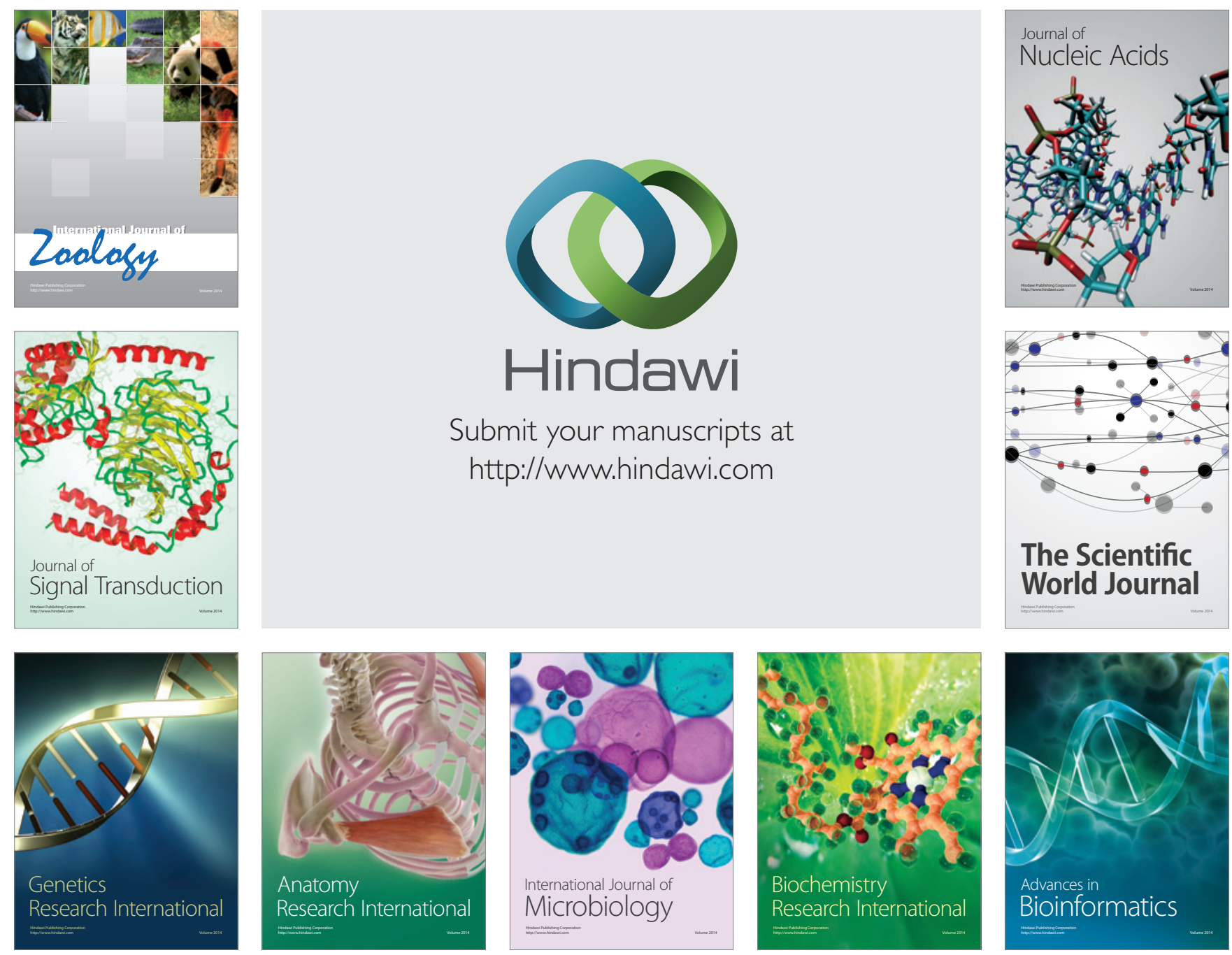

The Scientific World Journal
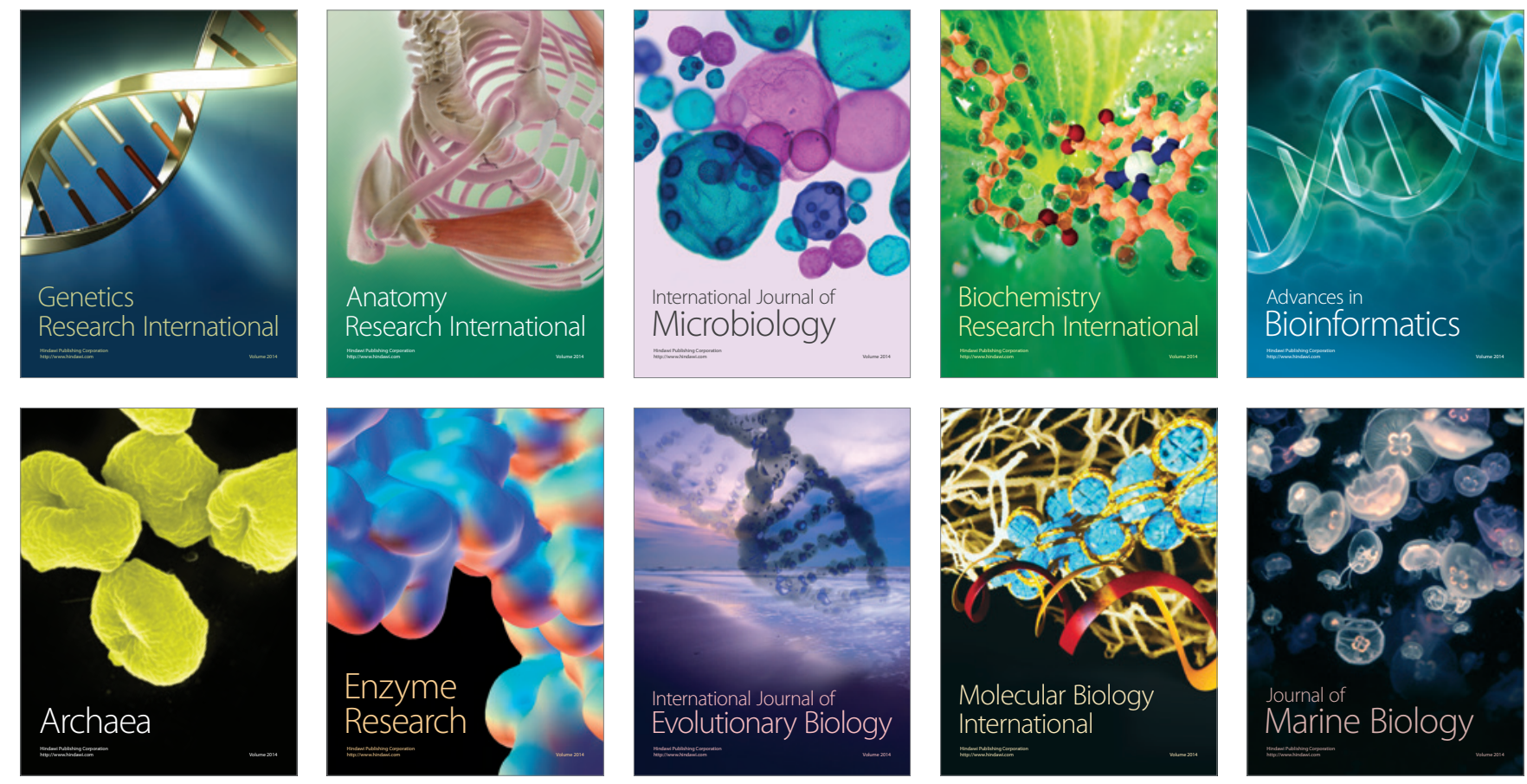